\title{
Влияние заработной платы в европейской части России на миграцию в районах Крайнего Севера ${ }^{1,2}$
}

\author{
М.А. ГИЛЬТМАН*, Н.В. ОБУХОВИЧ**, \\ Н.И. ЛАРИОНОВА***
}

\begin{abstract}
*Марина Андреевна Гильтман - кандидат экономических наук, профессор, кафедра экономики и финансов, ФГАОУ ВО «Тюменский государственный университет». Адрес: 625003, Тюмень, ул. Володарского, д. 6. E-mail: giltman@rambler.ru

**Наталья Владимировна Обухович - кандидат экономических наук, доцент, кафедра экономики и финансов, ФГАОУ ВО «Тюменский государственный университет». Адрес: 625003, Тюмень, ул. Володарского, д. 6. E-mail: o.n.v@mail.ru

***Наталия Ивановна Ларионова - кандидат экономических наук, доцент, кафедра экономической теории и эконометрики, ФГАОУ ВО «Казанский федеральный университет». Адрес: 420008, Казань, ул. Кремлевская, д. 18. E-mail: natasha-lari@mail.ru
\end{abstract}

Цитирование: Гильтман М.А., Обухович Н.В., Ларионова Н.И. (2020) Влияние заработной платы в европейской части России на миграцию в районах Крайнего Севера // Мир России. Т. 29. № 3. С. 28-50. DOI: 10.17323/1811-038X-2020-29-3-28-50

В статье анализируются процессы снижения численности населения российского Севера, связанные с оттоком трудовых ресурсов. Основная гипотеза исследования: повышение заработной платы в европейской части России оказывает отрицательное влияние на миграцию в районах Крайнего Севера. Отправной точкой работы послужил анализ процессов убыли населения на территории российской Арктики, смоделирована зависимость миграции от спроса на труд в добывающих районах российского Севера. Спрос на труд формируется крупными добывающими компаниями, что приводит к локализаичии населения в крупных городах и зависимости северного рынка труда от ресурсного цикла, при этом переход между цииклами задает требования к структуре трудовых и капитальных ресурсов. Социально-экономические процессы в европейской части России также оказывают влияние на территории Крайнего Севера. Для эконометрическо-

\footnotetext{
1 Авторы выражают искреннюю благодарность Ольге Анатольевне Демидовой (НИУ ВШЭ) за ценные комментарии и замечания.

2 Статья опубликована в рамках проекта НИУ ВШЭ по поддержке публикаций авторов российских образовательных и научных организаций «Университетское партнерство».
} 
го моделирования данных проиессов субъекты РФ разделены на две группы - европейский и северный регионы. К европейской части было отнесено 53 субъекта РФ, в группу районов Крайнего Севера вошли 12 субъектов РФ. Источником эмпирических данных послужили агрегированные региональные данные Росстата. Гипотеза исследования проверяется с помощью построения индексов Морана и оценивания пространственных моделей с фиксированными эффектами на панельных данных за 2010-2017 г2. В модели включены переменные, характеризующие экономическое развитие регионов, рынок труда, годы макрошоков, население. Показано, что отток населения из районов Крайнего Севера связан с повышением заработной платы в европейской части России. Также положительно значимы оиенки пространственных эффектов для повышения зарплаты на Севере. В то же время миграционные процессы в пределах районов Севера не связаны между собой. В качестве рекомендаций для социально-экономической политики развития Арктической зоны РФ предложено расширение спроса на труд в северных регионах, при этом особое внимание следует уделять привлечению высококвалифицированных кадров и, как следствие, концентрации усилий в сфере увеличения конкурентоспособности северных территорий.

Ключевые слова: Арктика, заработная плата, спрос на труд, миграция, локальные рынки труда, население Арктики, население Севера, компенсационные различия

\section{Введение}

Актуальность развития Арктической зоны Российской Федерации признается как политиками (о чем, например, свидетельствует принятие и реализация «Стратегии развития Арктической зоны Российской Федерации и обеспечения национальной безопасности на период до 2020 г.» (далее - Стратегия)), так и учеными [Пилясов 2015; Богоявленский, Богоявленский 2017; Трофимов 2019]. К сожалению, в настоящее время развитие этих территорий сдерживается множеством социально-экономических рисков и угроз, в том числе отрицательными демографическими процессами в большинстве приарктических субъектов Российской Федерации, оттоком трудовых ресурсов (особенно высококвалифицированных) в климатически более благоприятные районы России и за границу, отсутствием эффективной системы подготовки кадров, дисбалансом между спросом и предложением трудовых ресурсов в территориальном и профессиональном отношении (дефицит кадров рабочих и инженерных профессий и переизбыток невостребованных специалистов, а также людей, не имеющих профессионального образования). Фиксация в Стратегии данных рисков и угроз отражает заинтересованность государства в формировании, привлечении и удержании трудовых ресурсов, необходимых для реализации приоритетных стратегических направлений развития российской Арктики. В связи с этим Стратегией предусмотрен комплекс мер по улучшению качества жизни населения, проживающего и работающего в Арктической зоне РФ. Механизмами реализации комплекса мер, способствующих формированию, привлечению и удержанию трудовых ресурсов, являются государственные программы «Социально-экономическое развитие Арктической зоны Российской Федерации», 
«Содействие занятости населения», «Развитие образования» и другие ${ }^{3}$. Финансирование программных мероприятий предусматривается как за счет бюджетных средств (федеральных и региональных), так и на основе государственно-частного партнерства.

Несмотря на такое пристальное внимание государства к проблемам оттока и удержания высококвалифицированных кадров в северных районах ${ }^{4}$, их население продолжает сокращаться (рисунок 1), а имеющийся состав населения и трудовых иммигрантов не позволяет в полной мере удовлетворить спрос на труд работников необходимой квалификации [Соколова 2016].

Исследователи миграции называют главной причиной миграции из восточных и северных регионов России локализацию спроса на труд в европейской части страны [Bignebat 2006; Mkrtchyan, Karachurina 2015; Sardadvar, Vakulenko 2016]. Рост спроса на труд в регионах европейской части России косвенно отражался на повышении там заработной платы: так, отношение среднемесячной номинальной начисленной заработной платы в районах Крайнего Севера и приравненных к ним местностях к соответствующему среднероссийскому показателю в 2000 г. составляло 2,3 раза, в 2005 г. - 1,9 раза, в 2010-2017 гг. - 1,6 раза. Аналогичное соотношение, например, для Центрального федерального округа в 2000 г. - 0,98 раз, в 2005 г. - 1,12 раз, в 2017 г. - 1,24 раза. Таким образом, концентрация спроса на труд в европейских регионах РФ привела к тому, что разница в оплате труда на Севере и в Центральной России постепенно сокращается. Авторы не обладают достаточными данными для обоснованного утверждения, но можно предположить, что для высококвалифицированных специалистов северная заработная плата не является весомым аргументом для проживания в суровых климатических условиях по причине достаточного размера доходов в районах с более благоприятным климатом.

\footnotetext{
3 «Социально-экономическое развитие Арктической зоны Российской Федерации» (2014) // http://www.consultant.ru/cons/cgi/online.cgi?req=doc\&ts=187268081402070966320337948\&cacheid=F449F21DA8 4496A04CDAE4A881E40D07\&mode=splus\&base $=$ LAW\&n=349915\&rnd=C54AFEDA398FF1E60065E17EAE70824F\#cqcurxfbaq0; «Содействие занятости населения» (2014) // http://www.consultant.ru/cons/cgi/online.cgi?req=d oc\&ts $=126420905902594811400451038 \&$ cacheid $=$ A3D15C6683E3232BBF5F330FE6E31 A6B \&mode $=$ splus $\&$ base $=\mathrm{L}$ AW\&n=349268\&rnd=0.6976163358751428\#cj4hk44d3pk; «Развитие образования» (2017) // http://www.consultant. $\mathrm{ru} /$ cons/cgi/online.cgi? rnd=C54AFEDA398FF1E60065E17EAE70824F\&req=doc\&base $=$ LAW\&n=349563\&dst=10001 9\&fld=134\&REFFIELD=134\&REFDST =2779\&REFDOC=349915\&REFBASE=LAW\&stat=refcode\%3D16876\%3Bd stident\%3D100019\%3Bindex\%3D487\#1q7cex0yudi
}

4 Отметим, что в РФ выделяют районы Крайнего Севера и Арктическую зону, при этом районы Крайнего Севера - это более общая категория, включающая в себя большую территорию. Как правило, Крайний Север чаще выступает объектом анализа в исследованиях российских регионов, а Арктическая зона РФ - в международных сопоставлениях как часть Арктики, входящей в состав России. В нашем исследовании под северными регионами мы будем понимать районы Крайнего Севера как территорию с наиболее схожими условиями жизни и процессами, протекающими на локальных рынках труда, поскольку именно такое понимание отвечает задачам исследования. В то же время экономические и социальные процессы в российской Арктике и районах Крайнего Севера очень похожи, поэтому мы считаем допустимым в ряде случаев переход от анализа процессов в районах Крайнего Севера к рассмотрению процессов в Арктической зоне, особенно при описании международных тенденций, происходящих на Севере. Официально районы Крайнего Севера определены в «Перечне районов Крайнего Севера и местностей, приравненных к районам Крайнего Севера, на которые распространяется действие Указов Президиума Верховного Совета СССР от 10 февраля 1960 г. и от 26 сентября 1967 г. о льготах для лиц, работающих в этих районах и местностях», утв. Постановлением Совмина СССР от 10.11.1967 № 1029». Там, где необходимо использование статистических данных, мы включаем в анализ (рисунки, графики, регрессии и т.д.) только те субъекты РФ, территория которых полностью отнесена к районам Крайнего Севера, согласно названному выше Перечню. Данное ограничение вызвано тем, что Росстат по большинству индикаторов представляет в открытом доступе только агрегированные данные по регионам в целом без возможности выделения отдельных поселений. 
Мировой тренд, напротив, состоит в движении квалифицированных работников с Юга на Север [Dølvik, Eldring 2006; Samet 2013]. Активно растущие компании северных стран предъявляют спрос на высококвалифицированных специалистов и, испытывая дефицит в рабочей силе высокого качества, выходят на мировой рынок труда, предлагая конкурентоспособную заработную плату и условия занятости [Foldspang et al. 2013]. В итоге в последние два десятилетия мы наблюдаем рост населения в арктических поселениях Канады, США, Норвегии и других стран, а также убыль населения из северных регионов России [Heleniak 2014; Emelyanova 2018; Jungsberg et al. 2019].

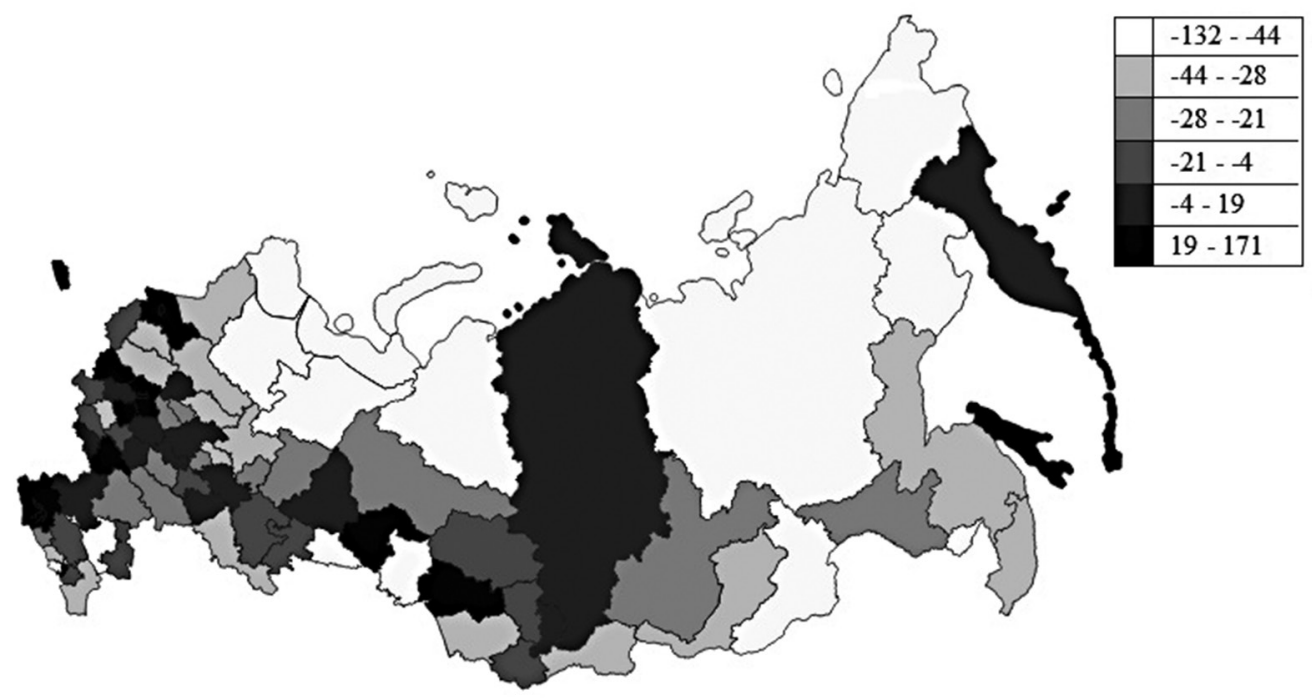

Рисунок 1. Коэффициент миграционного прироста на 10 тыс. чел. населения в 2017 г.

Источник: составлено авторами помощью сервиса QGIS по данным портала GADM и Росстата

Теоретически необходимость более высокой заработной платы для привлечения квалифицированных работников на Север, т.е. в районы со сложными жизненными условиями ${ }^{5}$, можно объяснить с помощью модели локальных

\footnotetext{
5 Результаты медико-физиологических исследований подтверждают необратимые последствия в изменениях организма при пребывании свыше 10 лет в условиях Крайнего Севера и содержат рекомендации работать там не более 5-7 лет подряд [Силин 2015]. Исследователи отмечают, что человеческий организм в Арктической зоне функционирует в более напряженном режиме, заметно истощая физиологические резервы: происходит перестройка всех видов обмена веществ и гормонального регулирования, повышен риск заболеваний сердечнососудистой системы и органов дыхания, костно-мышечной и нервной систем, органов пищеварения, поражения зубов и костной ткани [Воронц̧ова, Воронцов 2019]. Здоровью человека угрожают как природно-климатические факторы (холод, подвижность воздушных масс с частыми сменами циклонов и антициклонов, повышенная электромагнитная активность, повышенное ионизирующее излучение, низкая абсолютная влажность воздуха и высокая относительная, сниженная парциальная плотность кислорода в воздухе, частые и резкие перепады атмосферного давления, выраженный сезонный фотопериодизм), так и антропогенные (вредные выбросы
} 
рынков труда [Rosen 1979; Roback 1982; Moretti 2011] и теории компенсационных различий (compensative differentials) [Coelho, Ghali 1971; Greenwood et al. 1991; Bignebat 2003]. В указанной модели решение о миграции индивид принимает, сравнивая преимущества территорий (amenities) и размер заработной платы. Согласно теории компенсационных различий, для привлечения работников на территории, обладающие меньшими региональными преимуществами, работодатели вынуждены платить им более высокую заработную плату, чтобы компенсировать отрицательную полезность работника от проживания на данной территории ${ }^{6}$. Таким образом, повышение заработной платы в европейских регионах России вполне могло стать причиной оттока населения из северных регионов. В представленном исследовании мы попытаемся ответить на вопрос: увеличивает ли повышение заработной платы в регионах европейской части России миграционный отток из районов Крайнего Севера? Методология исследования сводится к оценке панельной модели с фиксированными эффектами с включением в нее пространственного лага и делением общей матрицы обратных расстояний на четыре части, что позволяет количественно измерить наличие влияния динамики заработной платы в регионах европейской части России на миграцию в районах Крайнего Севера. В работе использованы агрегированные региональные данные Росстата за 2010-2017 гг.

\section{Миграция и занятость в северных регионах: мировой контекст и российские особенности}

Геополитическое положение и важность арктических и приарктических территорий часто вызывают необходимость их исследования на наднациональном уровне [Larsen, Fondahl 2014; Heleniak 2014; Jungsberg et al. 2019]. Такие исследования показывают схожесть и различия социальных и экономических процессов в Арктике, которые могут протекать иначе, чем те же процессы на других территориях.

и сбросы нефтедобывающих производств, горнодобывающих и горно-обогатительных комплексов, а также предприятий черной и цветной металлургии; радиация, накопленная в результате ядерных испытаний прошлых лет и от действующих техногенных источников радиации), усиливая негативное совместное негативное воздействие (эффект «арктической синергии») [Воронц̧ова, Воронцов 2019; Сюрин, Ковщов 2019]. Это повышает риски профессиональных заболеваний [Сюрин, Ковщов 2019] и приводит к значительным трудопотерям, ранней инвалидизации и снижению продолжительности жизни [Воронц̧ова, Воронцяов 2019]. Риску профессиональных заболеваний в условиях Арктики подвержены прежде всего работники, занятые добычей каменного угля, металлических и апатит-нефелиновых руд (нефти и газа значительно реже), затем в порядке убывания в металлургическом производстве, строительстве и транспорте [Сюрин, Ковшов 2019]. При вахтовом методе работы здоровье работников на Крайнем Севере подвергается воздействию дополнительных неблагоприятных факторов (необходимости длительного нахождения в замкнутом пространстве с незнакомыми людьми, различию в природных условиях мест проживания и работы, необходимости постоянной адаптации и реадаптации, повышенным физическим и эмоциональным нагрузкам). Подобные сверхнагрузки на организм приводят к фрустрации, эмоциональному выгоранию и психическим заболеваниям вахтовых работников. При этом их легче переносят те, кто постоянно проживает на приарктических территориях, чем вахтовики из средней полосы и южных территорий России [Силин 2015].

6 Положительные amenities, т.е. на самом деле преимущества от проживания в северных районах могут наблюдаться только для коренного населения, но в настоящее время в Арктике коренные жители составляют примерно $10 \%$ от общей численности населения. Исключения представляют Канада (около половины населения Арктики коренные жители, что может объясняться широким распространением вахтового метода работы) и Гренландия, где коренные жители - это большинство постоянного населения [Jungsberg et al. 2019]. 
Например, большинство арктических регионов, несмотря на страновую принадлежность, характеризуются более высокой рождаемостью и смертностью, меньшей продолжительностью жизни и более молодым составом населения [Hamilton, Mitiguy 2009]. Для многих северных стран характерно преобладание мужского населения над женским, что объясняется особенностями миграционных процессов, связанных со структурой экономики и, следовательно, структурой рабочих мест [Heleniak, Bogoyavlensky 2015]. Во всех странах возможности занятости на Севере гораздо важнее для динамики миграционного прироста или оттока по сравнению с регионами с более благоприятным климатом [Larsen, Fondahl 2014], при этом занятость и миграция часто зависят от динамики добычи ресурсов [Rolfe et al. 2007; Пилясов 2018]. Высокую мобильность населения северных регионов косвенно можно увидеть и через структуру собственности на жилье: арендованное жилье часто предоставляется работнику в связи с трудоустройством в рамках трудового договора. Гренландия, Нунавик, Нунавут, Чукотка, Шпицберген, Таймыр и Ненецкий автономный округ - регионы, где преобладает аренда жилья; на Фарерских островах почти все жилища находятся в частной собственности; в ХМАО и Саха (Якутии) - более 85\% квартир [Jungsberg et al. 2019].

Характер региональной миграции на Севере часто напоминает цикл взлетов и падений, которые исторически были связаны с такими крупномасштабными промышленными проектами, как строительство трубопроводов, разведка и добыча нефти, военные действия. Например, рост населения на Аляске был обусловлен строительством нефтепровода в 1970-х гг, а в российской Арктике - с началом добычи углеводородного сырья в 1960-1970-е гг. В Канаде и на Аляске миграционные циклы связаны с добычей ресурсов и, соответственно, изменением спроса на рабочую силу [Emelyanova 2017]. При этом исследования показывают, что экономика северных территорий зачастую контрциклична, что приводит к притоку мигрантов в периоды высокой безработицы в других регионах. Основная часть мигрантов стремится в большие города, особенно женщины, которые достигают более высоких уровней образования [Khoreva et al. 2019; Heleniak, Bogoyavlensky 2015]. Концентрации населения в крупных городах характерна для всех северных стран [Howe 2009; Howe, Huskey, Berman 2014]. Урбанизация Севера во многом связана с локализацией спроса на труд в городах, где преимущественно занято как постоянное население, так и большинство трудовых мигрантов [Huskey, Southcott 2010; Larsen, Fondahl 2014]. В 2017 г. из 20 городов Арктики, имеющих численность населения свыше 40 тыс. чел., 12 были расположены в России, 7 - в Западной Европе, 1 - в США. Начиная с 1990-х гг. численность населения выросла во всех зарубежных арктических городах и только в 3 российских: Новом Уренгое, Ноябрьске и Североморске [Фаузер, Смирнов 2018]. Схемы расселения показывают, что две трети населения Арктики живут в населенных пунктах с населением более 10 тыс. чел., и лишь некоторые регионы характеризуются рассредоточенным населением, проживающим в многочисленных небольших населенных пунктах (менее 5 тыс. жителей). К таким исключениям можно отнести Чукотку, Нунавут, Гренландию, Фарерские острова и Финнмарк, - все это населенные пункты, характеризующиеся преобладанием коренных северных народов [Karlsdóttir, Greve Harbo 2017]. Угасание маленьких населенных пунктов характерно и для российского Севера, при этом в европейской части российской Арктики снижение численности населения уже выступает как угроза устойчивому развитию 
промышленности [Khoreva et al. 2019]. Основные факторы, приводящие к оттоку населения, - зарплата и уровень занятости, стоимость переезда и неразвитая инфраструктура [De Haas 2010; Huskey, Southcott 2010]. Значительную роль в миграционных процессах на Севере как в России, так и за рубежом играет фактор образования: так, в странах северной Атлантики молодежь уезжает за образованием, и большинство из них обратно не возвращается, причем население северных регионов характеризуются более высоким уровнем образования для женщин [Hansen et al. 2012], что верно и для российского Севера [Гильтман 2017].

При схожести описанных выше процессов демографические характеристики арктических регионов значительно различаются по численности населения, темпам роста, структуре населенных пунктов, рождаемости и характеру миграции [Karlsdóttir, Greve Harbo 2017]. Так, в 1990-2018 гг. население арктических территорий зарубежных стран росло везде, кроме некоторых регионов Швеции и Финляндии. В России проживает около половины населения Мировой Арктики, и оно стремительно сокращается [Фаузер, Смирнов 2018]. Наиболее драматически снижение численности населения происходит в Магаданской области и Чукотском АО: там оно уменьшилось по сравнению с 1990 г. почти на 70\% (2018 г.). Исключение составляют ХМАО и ЯНАО, где в целом за период наблюдался прирост населения, причем преимущественно в городах [Heleniak 2014; Emelyanova 2018; Jungsberg et al. 2019]. Вместе с населением на протяжении последних 20 лет на Севере России сокращалась и занятость: в 2018 г. по сравнению с 1998 г. численность занятых уменьшилась на 19\% (рисунок 2). При этом показатель численности занятых (в отличие от численности населения) учитывает и занятых на Севере мигрантов, включая вахтовиков. С нашей точки зрения, здесь мы можем говорить о сужении спроса на труд в северных регионах страны. Формально для такого утверждения нам нужна статистика по вакантным рабочим местам, которой мы не располагаем, но, как правило, вакансий всегда намного меньше, чем работающих, и именно численность занятых является основным индикатором спроса на труд [Капелюшников, Ощепков 2014].

В чем причины сокращения населения и численности занятых на Крайнем Севере России? Исходя из вышесказанного, мы можем предложить два объяснения. Первое основано на понимании процессов, уникальных для Арктики. На самом деле высокая мобильность населения и ее зависимость от возможностей занятости делают рынок труда северных территорий РФ похожими на рынки труда других северных стран [Гильтман 2017]. Мобильность населения на локальных северных рынках труда определяется спросом, который производен по своей природе и зависит от развития экономики определенной территории. Правительства и корпорации часто рассматривают добывающую промышленность как ресурс для устойчивого развития Арктики, однако волатильность цен на сырьевые товары, политическая и экономическая обстановка вокруг добывающей отрасли ставят под вопрос ее возможность стать фактором долгосрочного социально-экономического развития [Rolfe et al. 2007]. А.Н. Пилясов отмечает, что, поскольку арктическая экономика имеет ресурсный профиль, экономические и социальные процессы определяются именно циклом ресурсного освоения территории [Пилясов 2018]. Так, в Норвегии, характеризующейся положительным сальдо миграции, Statoil и другие компании с 2014 г. сократили в нефтегазовом секторе более 35 тыс. рабочих мест, что привело к росту безработицы в стране на 2\% [Wilson, Stammler 2016]. 
Даже если в отрасли нет серьезных кризисов, процессы роботизации и оптимизации производства все равно могут привести к сокращению рабочих мест, тем более что современные добывающие компании, как правило, высокотехнологичны [Tano, Pettersson, Stjernström 2016].

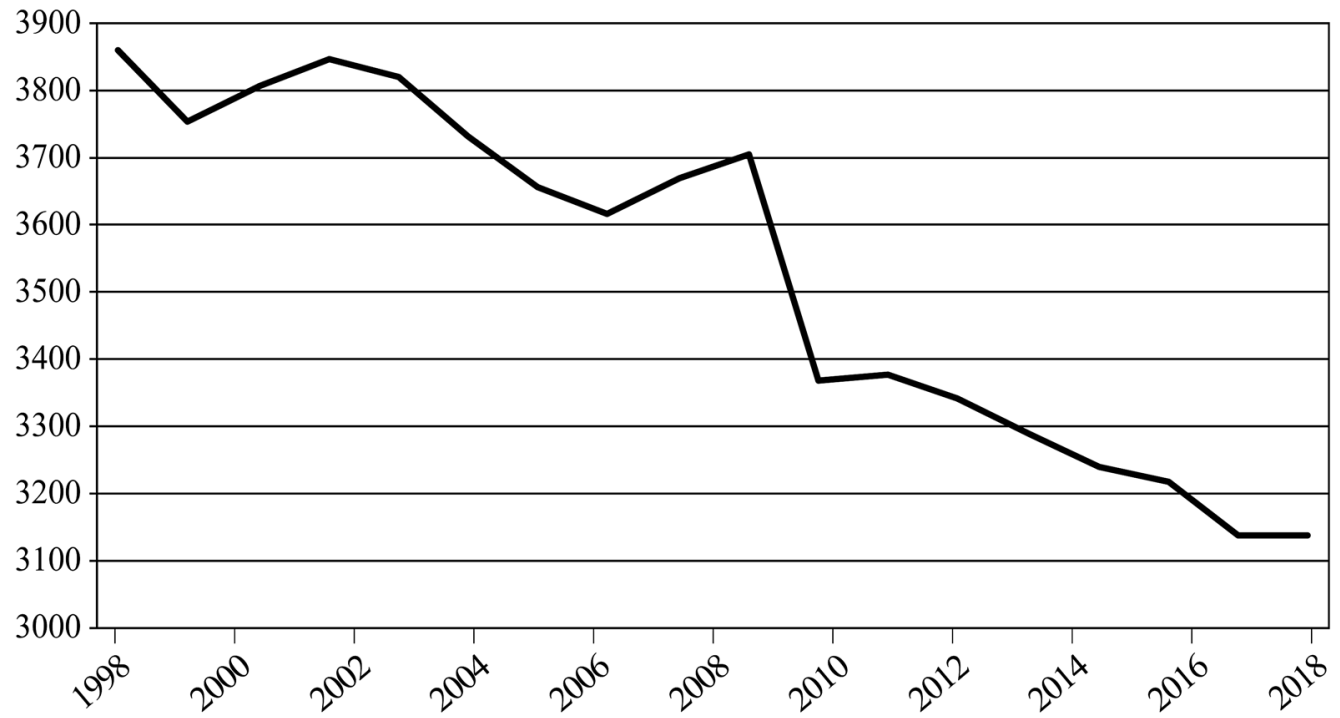

Рисунок 2. Среднесписочная численность работников организаций в районах Крайнего Севера и приравненных к ним местностях (без субъектов малого предпринимательства), тыс. чел.

Источник: составлено авторами по данным Росстата

Длительная история промышленного освоения российского Севера, описанная в ряде предшествующих эмпирических исследований, дает нам возможность смоделировать зависимость миграции от спроса на труд в добывающих регионах российского Севера:

1. На начальных стадиях ресурсного цикла происходит масштабная мобилизация трудовых, материальных, финансовых ресурсов [Пилясов 2018]. Эффект экономии от масштаба при развитии инфраструктуры и освоении месторождений дает преимущества крупным компаниям [Крюков 2019], они и монополизируют спрос на труд работников различных профессий и уровней квалификации.

2. По мере освоения и истощения крупных месторождений природных ресурсов растет значимость фактора повышенной гибкости и интеллектуальной деятельности по освоению более специфичных и очень рассредоточенных меньших месторождений, обеспечиваемой инновационно-ориентированными компаниями и уникальными специалистами, которые обслуживают отдельные производственные процессы [Крюков 2019]. Соответственно, спрос на труд рассредоточивается, а требования к профессиям и уровням квалификации работников конкретизируются и усложняются с учетом поставленных задач. 
3. Несмотря на то, что полный цикл добычи минеральных и топливно-энергетических ресурсов может длиться десятилетиями, трудовые ресурсы арктических территорий отличает колоссальная мобильность [Пилясов 2018], а последовательный переход между стадиями ресурсного цикла задает требования к количеству, качеству и структуре трудовых и капитальных ресурсов.

4. Современная система расселения на отдаленных и окраинных территориях российских Севера и Арктики формировалась в основном с 1970-х до 1990-х гг. на основе многоуровневого подхода (постоянные и временные поселения) [Фаузер, Смирнов 2018]. Географическая удаленность северных и арктических месторождений минеральных и топливно-энергетических ресурсов от основной зоны поселений способствует доминированию временных форм пространственной близости - вахтовых поселений [Крюков 2019; Замятина, Пилясов 2017]. Вахтовая занятость распространена также в Канаде и Австралии, однако и здесь есть минусы: полученные рабочими деньги тратятся в других регионах, но тем не менее она остается одним из способов повышения гибкости спроса и предложения на рабочую силу в добывающих отраслях на Севере [Tano, Pettersson, Stjernström 2016]. Создание и содержание вахтовых поселений экономически более целесообразно, чем поддержание постоянных, ввиду снижения удельных затрат ресурсов и ограничения численности проживающих в них работников без переселения их семей [Силин 2015], при этом источники инвестиций (бюджетные и корпоративные) в трудовую мобильность распределяются по-разному, в связи с чем в России реализуется стратегия перепрофилирования моногородов в вахтовые поселения. Кроме того, создаются крупные инфраструктурные объекты временного назначения: морские платформы, трубопроводы, промыслы, производственные поселения [Крюков 2019].

Таким образом, спрос на труд локализуется на территориях с эксплуатируемыми месторождениями и формируется либо крупными компаниями, либо небольшими инновационными предприятиями в зависимости от стадии ресурсного цикла. Завершение одного ресурсного цикла и начало нового не только смещают локализацию спроса на труд, но и изменяют его объем и структуру, усиливают трудовую (особенно вахтовую) миграцию. Учитывая относительно небольшие объемы добычи отечественными компаниями топливно-энергетических ресурсов в Арктической зоне РФ, сокращению которых способствовали кризисные явления в экономике, списание без восполнения физически и морально устаревших судов и платформ бурового флота, высокая стоимость разведки, освоения и эксплуатации новых месторождений, дефицит инвестиционных ресурсов, санкционные запреты западных стран на поставки оборудования для работ в арктическом шельфе и другие факторы [Трофимов 2019], можно предположить некоторое затухание деловой активности даже в добывающих районах Крайнего Севера и сужение спроса на труд, что и объясняет сокращение численности населения и занятых.

Второе объяснение лежит за пределами Арктики и определяется социальноэкономическими процессами в других регионах страны, важнейшим из которых является то, что в настоящее время рынок труда России находится в крайне необычных условиях снижения численности трудовых ресурсов [Капелюшников, Ощепков 2014]. Следует отметить, что рынки труда России вне районов Крайнего Севера составляют примерно 95\% занятых в стране. Сокращение предложения труда в стране в целом приводит к тому, что работнику становится легче трудо- 
устроиться в районах с более благоприятными условиями, и необходимость ехать на Север с целью поиска рабочего места исчезает. Таким образом, падение численности трудовых ресурсов в России вполне могло стать одной из причин снижения доли занятых на Севере в общей численности занятых в РФ с почти 6\% (2000 г.) до 4,3\% (2018 г.). В европейских регионах России в 2000-2018 гг. было занято около 76-77\% всех работников, при этом необходимо учесть, что все большие города с наиболее конкурентными рынками также расположены преимущественно в западной части страны, где рынки труда остаются, согласно исследованиям, центрами концентрации работников с высокими запасами человеческого капитала [Fujita, Krugman, Venables 1999; Glaeser, Mare 2001; Moretti 2011]. Приближение размера заработной платы в европейской части РФ к зарплате на Севере, описанное во введении этой статьи, и концентрация спроса на труд в западных регионах делают их своеобразным мощным магнитом для индивидов, занятых на Севере, которые, судя по всему сказанному выше, в принципе обладают высокой склонностью к мобильности.

Кроме того, спрос на труд зависит и от производительности, а она, в свою очередь, - от уровня образования. Отток высококвалифицированных кадров из Арктических районов $\mathrm{P}^{7}$ привел к тому, что почти все арктические регионы РФ, кроме ЯНАО, уступают Аляске, Исландии, Норвегии, Финляндии и некоторым северным регионам Канады по доле населения с высшим образованием [Jungsberg et al. 2019]. Регионы российской Арктики лидируют по доле занятых в добывающей промышленности, а канадской и американской (Аляска) по доле занятых в сфере услуг среди всех арктических регионов всех стран мира [Jungsberg et al. 2019]; около 50\% работников российской Арктики заняты в госсекторе [Hansen, Bitsch, Zalkind 2013; Jungsberg et al. 2019]. В итоге в российской Арктике существенно меньше занятых, которые работают менее 30 часов в неделю: если в Норвегии этот показатель равен 56-60\%, то в России - не более 3\% [Jungsberg et al. 2019]. Эти данные еще раз подтверждают, что занятость в российской Арктике более интенсивна, а рынки труда менее конкурентны в сравнении с зарубежными северными странами и европейской частью РФ. С точки зрения квалифицированного работника, ограниченность возможностей занятости означает меньшие возможности для применения своих компетенций и карьерного роста, что крайне важно в условиях Арктики в силу отсутствия интересного досуга [Пилясов 2018] и географической отдаленности от больших городов европейской части страны с более конкурентными рынками труда. В экстремальных природных условиях Арктики с предельно суженной социальной сферой и скудными вариантами проведения досуга размер заработной платы и интересная работа становятся наиболее значимыми факторами для работника, особенно молодого, при решении вопросов о занятости и проживании на Севере [Пилясов 2018]. Следовательно, мы можем предполагать, что повышение заработной платы в регионах европейской части России, учитывая наличие там больших возможностей для занятости, более благоприятный климат и развитую инфраструктуру, оказывало негативное влияние на миграцию в районы Крайнего Севера.

\footnotetext{
7 Стратегия развития Арктической зоны Российской Федерации и обеспечения национальной безопасности на период до 2020 г.
} 


\section{Стратегия и результаты оценивания}

В нашей статье мы предполагаем, что отток населения из районов Крайнего Севера России может быть вызван повышением заработной платы в регионах европейской части страны ${ }^{8}$. Для оценивания этой гипотезы первым шагом было разделение регионов на эти две группы. В процессе группировки мы руководствовались географическим положением Уральских гор, следуя делению, описанному в работах Е.А. Коломак [Коломак 2010] и О.А. Демидовой [Демидова 2014] и перечнем районов Крайнего Севера, выбрав только те субъекты РФ, территория которых полностью отнесена к указанным районам. В итоге к европейской части России мы отнесли 53 субъекта РФ: Москву, Санкт-Петербург; Белгородскую, Брянскую, Владимирскую, Воронежскую, Ивановскую, Калужскую, Костромскую, Курскую, Липецкую, Московскую, Орловскую, Рязанскую, Смоленскую, Тамбовскую, Тверскую, Тульскую, Ярославскую, Вологодскую, Калининградскую, Ленинградскую, Новгородскую, Псковскую, Астраханскую, Волгоградскую, Ростовскую, Кировскую, Нижегородскую, Оренбургскую, Пензенскую, Самарскую, Саратовскую, Ульяновскую, Свердловскую и Челябинскую области; Республики Адыгея, Калмыкия, Дагестан, Ингушетия, Кабардино-Балкарская, Карачаево-Черкесская, Северная Осетия - Алания, Чеченская, Башкортостан, Марий Эл, Мордовия, Татарстан, Удмуртская, Чувашская; а также Ставропольский, Пермский и Краснодарский края. Крым и Севастополь не были включены по причине отсутствия данных за периоды ранее 2015 г. В группу районов Крайнего Севера вошли 12 субъектов РФ: Республики Карелия, Коми, Тыва, Саха (Якутия); Камчатский край; Архангельская, Мурманская, Магаданская, Сахалинская области - и три автономных округа: Ханты-Мансийский, Ямало-Ненецкий и Чукотский.

Далее мы оценили индексы Морана для коэффициента миграционного прироста на 10 тыс. чел. населения, прибывших на 10 тыс. чел. населения и выбывших на 10 тыс. чел. населения (таблица 1) за каждый год в период с 2010 до 2017 г. Значимость индексов Морана показывает наличие пространственной корреляции, означающей, что регионы оцениваемой группы могут влиять друг на друга. Наши оценки показали, что между северными регионами пространственной корреляции нет, т.е. миграционные процессы в разных районах Севера между собой не связаны. Индексы Морана для коэффициента миграционного прироста на 10 тыс. чел. населения значимы во все годы для всех регионов, оцененных вместе и для группы регионов европейской части страны. Для всех регионов индексы значимы почти во все годы также для прибывших и выбывших. Между субъектами европейской части страны пространственная корреляция присутствует для прибывших с 2012 г., а для выбывших - в 2010 г. и далее в 2014-2017 гг. Таким образом, выбытие населения из одних регионов европейской части России меньше всего связано с выбытием населения из других регионов, расположенных там же.

\footnotetext{
8 В ряде предшествующих работ пространственная зависимость отдельных показателей для групп российских регионов уже была выявлена [Kholodilin, Oshchepkov, Siliverstovs 2009; Коломак 2010; Lehmann, Silvagni 2013; Демидова 2014; Бураншина, Смирных 2018].
} 


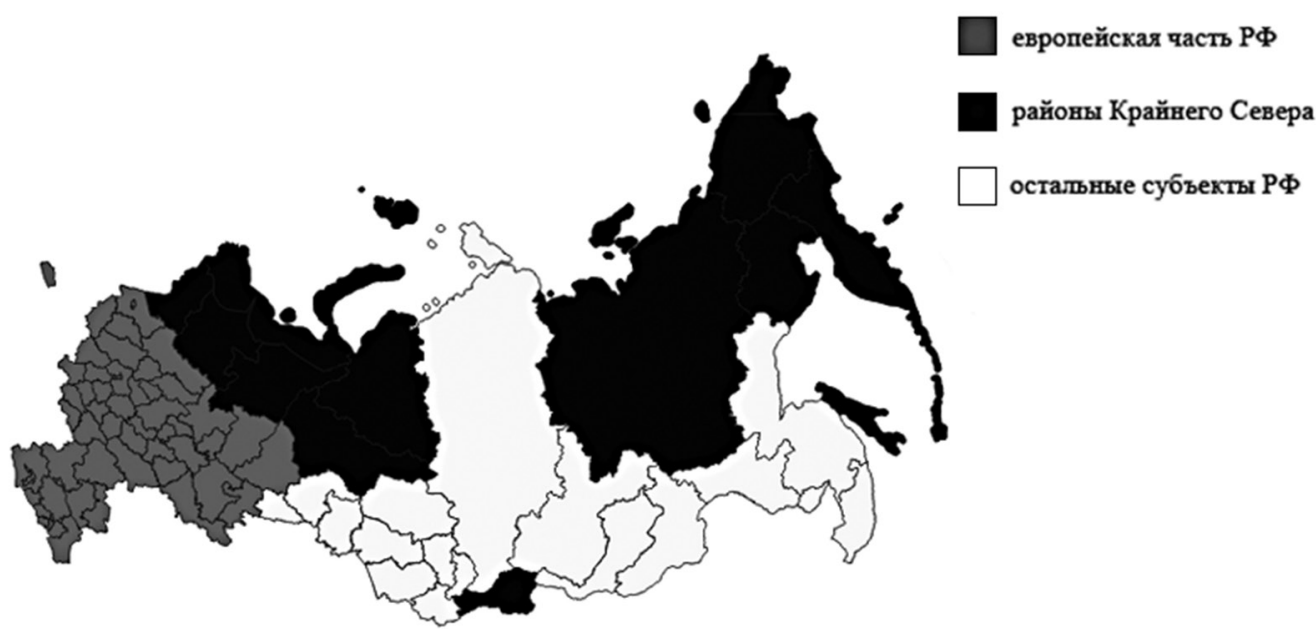

Рисунок 3. Принятое в данной работе деление регионов РФ

Источник: составлено авторами с помощью сервиса QGIS по данным портала GADM

Таблица 1. Индексы Морана для показателей миграции

\begin{tabular}{|c|c|c|c|c|c|c|c|c|c|}
\hline \multicolumn{3}{|c|}{ Коэффициент миграционного } \\
прироста на 10 тыс. чел. населен
\end{tabular}

$* \mathrm{p}<0,05 ; * * \mathrm{p}<0,01 ; * * * \mathrm{p}<0,001$

Источник: рассчитано авторами на основе данных Росстата

Для того чтобы оценить интересующее нас влияние изменения заработной платы в европейских регионах России на миграцию в районах Крайнего Севера, мы следуем подходу О.А. Демидовой [Демидова 2014, с. 25-26], т.е. вводим в модель пространственный лаг и делим общую матрицу обратных расстояний на четыре части. Отличием является то, что матрицы весов мы умножаем не на зависимую переменную Y, а на интересующую нас объясняющую переменную - заработную плату. Также, поскольку динамика в модели уже учтена через разные периоды времени 
( $\mathrm{t}$ для Y и t-1 для X), мы оцениваем не динамические, а обычные панельные модели с фиксированными эффектами‥ В итоге получается следующая модель:

$$
Y_{i, t}=X_{i, t-1} \beta+\rho W * \text { Wages }_{i, t-1}+\varepsilon_{i, t}
$$

где Y - зависимые переменные трех видов: коэффициент миграционного прироста на 10 тыс. чел. населения, прибывшие на 10 тыс. чел. населения и выбывшие на 10 тыс. чел. населения; X - матрица независимых переменных; $\beta$ - оцениваемые коэффициенты; W - матрица весов, Wages - заработная плата; $\varepsilon$ - остатки; $\rho$ - пространственный коэффициент корреляции, при интерпретации результатов важны его знак и значимость; $\mathrm{i}$ - регион; $\mathrm{t}$ - период времени (год). Период t-1 традиционно используется для независимых переменных при оценках миграции (например, [Sardadvar, Vakulenko 2016]), т.к. предполагается, что индивиду необходимо время на принятие решения о миграции после изменения параметров X.

Стандартизированную взвешенную матрицу W, нормированную по строкам, делим на четыре части:

$$
W_{(65 \times 65)}=\left(\begin{array}{cc}
W e e(53 \times 53) & 0 \\
0 & 0
\end{array}\right)+\left(\begin{array}{cc}
0 & W e n \\
0 & 0
\end{array}\right)+\left(\begin{array}{cc}
0 & 0 \\
W n e & 0
\end{array}\right)+\left(\begin{array}{cc}
0 & 0 \\
0 & W n n(12 \times 12)
\end{array}\right),
$$

где матрица Wee отражает влияние изменения заработной платы в европейской части страны на оцениваемые показатели миграции там же; Wen - влияние изменения заработной платы на Севере на миграцию в европейской части страны; Wne - интересующее нас влияние изменения заработной платы в европейских регионах на миграцию на Севере; Wnn - влияние изменения заработной платы на Севере на миграцию на Севере. Таким образом, в каждой из моделей оцениваются коэффициенты $\rho^{\mathrm{ee}}$, $\rho^{\mathrm{en}}, \rho^{\text {ne }}, \rho^{\mathrm{nn}}$, показывающие наличие или отсутствие пространственной зависимости.

Формируя перечень объясняющих переменных, мы ориентировались на работу С. Сардадвара и Е. Вакуленко [Sardadvar, Vakulenko 2016], оценивавших межрегиональную миграцию в России, также включая в модель с фиксированными эффектами пространственные лаги для восточных и западных регионов. Объясняющие переменные, в итоге, включают в себя заработную плату (Wages) относительно регионального прожиточного минимума в IV квартале соответствующего года [Демидова 2014]; логарифм ВРП на душу населения (1GDPpc), дефлированный к ценам 2009 г. по ИПЦ; уровень безработицы, \% (Uneml); долю экономически активного населения с высшим образованием, \% (Tert); долю населения младше трудоспособного возраста, \% (Young); долю населения старше трудоспособного возраста, \% (Old); коэффициент Джини (Gini) как показатель неравенства доходов и временной фактор через бинарные переменные 2009 и 2015 (кризисных) годов, когда наблюдалось падение заработной платы.

\footnotetext{
9 В процессе исследования оценивались и модели со случайными эффектами, но предпочтения везде были отданы моделям с фиксированными эффектами по результатам теста Хаусмана.
} 
Таблица 2. Результаты оценивания моделей с фиксированными эффектами для показателей миграции в 2010-2017 гг.

\begin{tabular}{|c|c|c|c|}
\hline & $\begin{array}{c}\text { Коэффициент } \\
\text { миграционного прироста } \\
\text { на } 10 \text { тыс. чел. населения }\end{array}$ & $\begin{array}{c}\text { Прибывшие } \\
\text { на } 10 \text { тыс. чел. } \\
\text { населения }\end{array}$ & $\begin{array}{c}\text { Выбывшие } \\
\text { на } 10 \text { тыс. чел. } \\
\text { населения }\end{array}$ \\
\hline Wages & $\begin{array}{c}25,89 * * * \\
(9,73)\end{array}$ & - & - \\
\hline WagesEu & - & $\begin{array}{c}15,78 \\
(17,39)\end{array}$ & $\begin{array}{l}-19,11 \\
(19,75)\end{array}$ \\
\hline WagesN & -- & $\begin{array}{c}174,11 * * * \\
(26,13)\end{array}$ & $\begin{array}{c}117,50 * * * \\
(29,51)\end{array}$ \\
\hline Uneml & $\begin{array}{c}0,77 \\
(0,95) \\
\end{array}$ & $\begin{array}{c}1,86 \\
(1,46) \\
\end{array}$ & $\begin{array}{c}0,29 \\
(1,64) \\
\end{array}$ \\
\hline 1GDPpc & - & $\begin{array}{l}55,58^{* * *} \\
(28,05) \\
\end{array}$ & - \\
\hline 1GDPpcEu & $\begin{array}{c}2,88 \\
(22,25) \\
\end{array}$ & - & $\begin{array}{c}131,40 * * * \\
(38,35)\end{array}$ \\
\hline lGDPpcN & $\begin{array}{c}-124,29 * * * \\
(30,63)\end{array}$ & - & $\begin{array}{c}282,20 * * * \\
(53,80)\end{array}$ \\
\hline YoungEu & $\begin{array}{l}-4,00 \\
(3,50) \\
\end{array}$ & $\begin{array}{c}29,29 * * * \\
(5,66)\end{array}$ & $\begin{array}{c}47,97 * * * \\
(6,37) \\
\end{array}$ \\
\hline YoungN & $\begin{array}{c}18,43 * * * \\
(4,81)\end{array}$ & $\begin{array}{c}-4,94 \\
(10,92) \\
\end{array}$ & $\begin{array}{l}-12,39 \\
(11,28) \\
\end{array}$ \\
\hline Old & $\begin{array}{c}3,46 \\
(2,66)\end{array}$ & - & - \\
\hline OldEu & - & $\begin{array}{c}0,46 \\
(4,70)\end{array}$ & $\begin{array}{c}14,02 * * * \\
(5,33)\end{array}$ \\
\hline OldN & - & $\begin{array}{c}41,76^{* * * *} \\
(6,34)\end{array}$ & $\begin{array}{c}51,68 * * * \\
(7,48)\end{array}$ \\
\hline Tert & $\begin{array}{c}-1,80 * * \\
(0,72) \\
\end{array}$ & - & $\begin{array}{l}-0,85 \\
(1,21) \\
\end{array}$ \\
\hline TertEu & - & $\begin{array}{c}1,41 \\
(1,18)\end{array}$ & - \\
\hline TertN & - & $\begin{array}{c}-8,03 * * * \\
(2,60)\end{array}$ & - \\
\hline Gini & $\begin{array}{c}41,27 \\
(56,84)\end{array}$ & $\begin{array}{l}-64,19 \\
(84,41)\end{array}$ & $\begin{array}{c}-131,16 \\
(95,30) \\
\end{array}$ \\
\hline WeeXWages $\left(\rho^{\mathrm{ee}}\right)$ & $\begin{array}{l}-33,30^{*} \\
(19,35)\end{array}$ & $\begin{array}{c}4,51 \\
(29,67)\end{array}$ & $\begin{array}{c}91,56 * * * \\
(33,60)\end{array}$ \\
\hline WnnXWages $\left(\rho^{\mathrm{nn}}\right)$ & $\begin{array}{l}-66,45 \\
(92,32) \\
\end{array}$ & $\begin{array}{c}93,29 \\
(142,06) \\
\end{array}$ & $\begin{array}{c}157,60 \\
(160,52) \\
\end{array}$ \\
\hline WenXWages $\left(\rho^{\mathrm{en}}\right)$ & $\begin{array}{c}83,18 \\
(213,82)\end{array}$ & $\begin{array}{l}788,75^{* *} \\
(316,24)\end{array}$ & $\begin{array}{c}1246,05^{* * *} \\
(356,82)\end{array}$ \\
\hline WneXWages $\left(\rho^{\text {ne }}\right)$ & $\begin{array}{l}-67,44^{*} \\
(36,73)\end{array}$ & $\begin{array}{c}-134,94 * * \\
(59,47)\end{array}$ & $\begin{array}{c}154,83^{* *} \\
(67,19)\end{array}$ \\
\hline year2009 & $\begin{array}{c}-11,04^{* *} \\
(5,14)\end{array}$ & $\begin{array}{c}-108,42^{* * *} \\
(7,58)\end{array}$ & $\begin{array}{c}0,12 \\
(8,58)\end{array}$ \\
\hline year2015 & $\begin{array}{c}5,79 \\
(4,87) \\
\end{array}$ & $\begin{array}{c}20,13 * * * \\
(7,18)\end{array}$ & $\begin{array}{c}51,49 * * * \\
(8,12)\end{array}$ \\
\hline cons & $\begin{array}{c}221,53 \\
(222,35) \\
\end{array}$ & $\begin{array}{c}-1148,34^{* * *} \\
(322,85) \\
\end{array}$ & $\begin{array}{c}-3235,28 * * * \\
(375,57) \\
\end{array}$ \\
\hline R2 (within) & 0,1375 & 0,7738 & 0,7991 \\
\hline $\mathrm{N}$ (obs) & 520 & 520 & 520 \\
\hline $\mathrm{N}$ (groups) & 65 & 65 & 65 \\
\hline
\end{tabular}

${ }^{*} \mathrm{p}<0,05 ; * * \mathrm{p}<0,01 ; * * * \mathrm{p}<0,001$ 
Анализируя модели, мы сначала разбивали объясняющие переменные на группы регионов (европейская часть и Север), затем тестировали полученные результаты на равенство коэффициентов между этими группами. Если различий между коэффициентами для разных групп не было, то в модель включали общую переменную без деления на группы. Результаты оценивания приведены в таблице 2.

Полученные результаты подтверждают наше предположение о том, что заработная плата в регионах европейской части России статистически значимо влияет на миграцию в районах Крайнего Севера. Знаки влияния также вполне логичны: повышение заработной платы в европейских регионах усиливает миграционную убыль населения в северных регионах (это мы видим из отрицательных знаков коэффициентов $\rho^{\text {ne }}$ для коэффициента миграционного прироста и прибывших, а также положительного знака для выбывшего населения). Прочие оценки пространственных эффектов показывают, что изменения заработной платы на Севере никак не влияют на показатели миграции на Севере, что еще раз подтверждает отсутствие пространственной корреляции между северными регионами (незначимость индексов Морана в таблице 1). Повышение заработной платы в европейской части страны отрицательно влияет на миграционный прирост и положительно на число выбывшего населения. Можно предположить, что такой эффект получается при повышении заработной платы в беднейших регионах (например, Южного федерального округа) и с переездом туда коренного населения, временно занятого ранее в Центральном федеральном округе. Положительно значимыми также оказались оценки пространственных эффектов для влияния роста заработной платы на Севере на численность прибывших и выбывших мигрантов в европейской части России. Объяснить полученный результат можно либо разными регионами прибытия и выбытия мигрантов (едут в более богатые регионы, а уезжают из бедных регионов, но при этом эффект от повышения заработной платы заметнее в средних оценках за счет ее роста в более богатых регионах), либо речь идет о разных пулах мигрантов: одни едут на север, привлеченные ростом заработной платы, а другие уезжают оттуда, несмотря на увеличение размера зарплат (по другим причинам).

Коэффициенты при некоторых других объясняющих переменных также оказались значимы. Значения многих из полученных коэффициентов можно объяснить логически, только принимая во внимание разнородность северных регионов (отсутствие пространственной корреляции между ними показали нам и индексы Морана). Условно говоря, есть очень богатые северные регионы (Ханты-Мансийский, Ямало-Ненецкий, Чукотский автономный округа), но есть и депрессивные северные регионы (Республики Тыва, Карелия и прочие), расположившиеся по уровню средней заработной платы между этими крайними группами. Заработная плата в европейских регионах также росла неравномерно.

В итоге из таблищы 2 видно, что повышение заработной платы в северных регионах оказывало положительное влияние как на прибывших, так и на выбывших мигрантов, что, вероятно, можно объяснить разными регионами прибытия и выбытия. Рост ВРП на душу населения в среднем для всех регионов приводил к повышению числа прибывших мигрантов, но для северных регионов эта взаимосвязь была обратной: увеличение рассматриваемого показателя снижало миграционный прирост и повышало число выбывшего населения. Это можно трактовать следующим образом: население покидало северные регионы, несмотря даже на экономический рост в них. Значимыми оказались коэффициенты для переменной доли 
населения моложе и старше трудоспособного возраста: чем выше были эти показатели, тем интенсивнее происходил миграционный оборот (значимость почти во всех оцененных уравнениях). Мы связываем полученный результат с интенсивными перемещениями молодежи во время учебы и переездом населения старших возрастов с Севера в более благоприятные климатические регионы.

\section{Выводы и дискуссия}

Российский Север и, в частности, Арктическая зона РФ являются стратегически важными территориями с точки зрения экономического развития и экономической безопасности страны. В последние несколько десятилетий одной из проблем развития северных территорий стал отток населения, особенно высококвалифицированных кадров, о чем сказано в «Стратегии развития Арктической зоны РФ». Одной из причин отрицательного миграционного прироста населения в районах Крайнего Севера может быть сокращение разрывов в оплате труда между Севером и остальными территориями страны, поскольку во многих регионах Центральной и даже Южной России заработная плата за последние 15 лет росла быстрее, чем на Севере. В представленной работе с помощью модели с фиксированными эффектами с добавлением пространственных лагов мы попытались оценить, на самом ли деле повышение заработной платы в европейских регионах страны влияло на миграцию в районах Крайнего Севера в 2010-2017 гг. Наши оценки однозначно подтверждают наличие такого влияния: рост заработной платы в европейских регионах страны отрицательно сказывался на миграционном приросте и числе прибывших и положительно - на численности выбывшего населения из районов Крайнего Севера России. Влияют ли на это в большей степени процессы, происходящие непосредственно в северных регионах или в европейской части страны, точно определить авторы статьи не могут, но результаты исследований, выполненных и на российских, и на зарубежных данных, показывают, что Север и Арктика становятся привлекательными для мигрантов при условии наличия там больших возможностей для занятости ${ }^{10}$, чем на локальных рынках труда территорий с более благоприятными условиями для жизни. Поэтому, с нашей точки зрения, государственные программы, задачами которых являются сохранение и/или увеличение численности населения северных регионов, должны быть направлены не на предложение труда, т.е. не на миграцию как таковую, а на расширение спроса на труд в районах Крайнего Севера. Такие инициативы начинают появляться в виде, например, законопроекта о распространении дальневосточного режима свободного порта на всю Арктическую зону РФ, разработанного Минвостокразвития в начале 2019 г., который после не очень удачного опыта создания портовой особой экономической зоны Мурманска, видимо, будет долго и детально дорабатываться.

В целом роль государства в арктической экономике выше, чем в неарктических территориях [Пилясов 2015]. Государственное регулирование северных

\footnotetext{
10 Возникающие прежде всего за счет большего количества рабочих мест, требованиям которых удовлетворяют навыки и компетенции трудовых мигрантов, с одной стороны, при этом, с другой стороны, характеристики рабочих мест, включая заработную плату, являются привлекательными для работников.
} 
территорий реализуется посредством стратегий и программ, но развитие конкурентных рынков труда в районах Крайнего Севера до сих пор в перечень приоритетных стратегических направлений развития Российской Арктики не входит, поэтому элементы регулирования северных локальных рынков труда рассеяны во множестве программ. Так, на вопрос «за счет каких трудовых ресурсов планируется новое хозяйственное освоение Арктики?» ответ частично дается в программах социально-экономического развития арктических территорий и региональных программах содействия занятости населения. При этом необходимость привлечения квалифицированных кадров указана для отдельных арктических территорий РФ: часть регионов планируют покрывать потребность в квалифицированных кадрах самостоятельно; часть регионов не обозначила своей позиции по этой проблеме [Гильтман, Обухович, Токарева 2019]. Вопрос, тем не менее, не праздный. Он связан не только с определением, в какой форме привлекать квалифицированных специалистов и как организовать их поселения (временные поселения вахтовых работников или постоянные поселения местных жителей и мигрантов), но и как сделать рынки труда районов Крайнего Севера конкурентными, а условия занятости - привлекательными для работников с высокими запасами человеческого капитала в условиях сильнейшей концентрации спроса на труд в регионах, более благоприятных для жизни.

Ряд высказанных нами предположений нуждаются в дальнейшем теоретическом и эмпирическом обосновании. Среди тем, которые следует рассмотреть с применением эконометрических методов, можно выделить моделирование взаимосвязи миграции и спроса на труд. Возможно, на миграционные потоки Севера оказывают влияние уровень безработицы и структура занятости в европейской части России. Недостаточно изученными с экономической точки зрения остаются проблемы, касающиеся условий проживания на Крайнем Севере, особенно аспекты, связанные с инфраструктурой. Также не хватает исследований, в которых проводится комплексная оценка государственной политики на Севере (особенно на рынке труда), и недостаточно количественных оценок ее влияния на процессы изменения численности населения и занятости на Крайнем Севере. Данная работа требует изучения большого пула программ, в которых рассеяны меры по регулированию Российской Арктики. Эта область выглядит перспективной не только для исследований российского Севера, но и для межстрановых сопоставлений.

\section{Литература}

Богоявленский В.И., Богоявленский И.В. (2017) Стратегия освоения ресурсов нефти и газа Арктики - обеспечение энергетической, экологической и экономической безопасности России // Геополитика и безопасность. № 3. С. 72-86.

Бураншина Н.А., Смирных Л.И. (2018) Человеческий капитал мигрантов и конвергенция российских регионов по заработной плате // Вопросы экономики. № 12. С. 121-138.

Воронцова Е.В., Воронцов А.Л. (2019) Состояние окружающей среды и здоровье человека в Арктической медицине: медицинский и социально-правовой аспект // Якутский медицинский журнал. № 3. С. 85-90.

Гильтман М.А. (2017) Занятость на Севере России: анализ на основе микроданных // Журнал Новой экономической ассоциации. № 3(35). С. 103-124. 
Гильтман М.А., Обухович Н.В., Токарева О.Е. (2019) Активная и пассивная политика на российском рынке труда: централизация или регионализация? // Вопросы экономики. № 6. C. 79-98.

Демидова О.А. (2014) Пространственно-авторегрессионная модель для двух групп взаимосвязанных регионов (на примере восточной и западной части России) // Прикладная эконометрика. № 34(2). С. 19-35.

Замятина Н.Ю., Пилясов А.Н. (2017) Концепция близости: зарубежный опыт и перспективы применения в России // Известия РАН. Серия Географическая. № 3. С. 8-21.

Капелюшников Р.И., Ощепков А.Ю. (2014) Российский рынок труда: парадоксы посткризисного развития // Вопросы экономики. № 7. С. 66-92.

Коломак Е.А. (2010) Пространственные экстерналии как ресурс экономического роста // Регион: экономика и социология. № 4. С. 73-87.

Крюков В.А. (2019) Моногорода и освоение сырьевых ресурсов на стадии высокой степени зрелости ресурсной базы // Вестник КемГУ. Серия: Политические, социологические и экономические науки. № 1. С. 98-105.

Пилясов А.Н. (2015) Российский арктический фронтир: парадоксы развития // Регион: экономика и социология. № 3(87). С. 3-36.

Пилясов А.Н. (2018) Арктическая диагностика: плох не метр - явление другое // Север и рынок: формирование экономического порядка. № 5(61). С. 35-54.

Силин А.Н. (2015) Социологические аспекты вахтового труда на территориях севера Западной Сибири // Экономические и социальные перемены: факты, тенденции, прогно3. № 4(40). С. 109-123.

Соколова Ф. Х. (2016) Миграционные процессы в Российской Арктике // Арктика и Север. № 25. С. $158-172$.

Сюрин С.А., Ковшов А.А. (2019) Условия труда и риск профессиональной патологии на предприятиях Арктической зоны Российской Федерации // Экология человека. № 10. С. 15-23.

Трофимов С.Е. (2019) Арктический шельф как стратегический регион развития российской экономики // Вопросы экономики. № 7. С. 147-160.

Фаузер В.В., Смирнов А.В. (2018) Мировая Арктика: природные ресурсы, расселение населения, экономика // Арктика: экология и экономика. № 3(31). С. 6-22.

Bignebat C. (2003) Spatial Dispersion of Wages in Russia: Does Transition Reduce Inequality on Regional Labour Markets? Paris: TEAM, University of Paris1\&CNRS.

Bignebat C. (2006) Labour Market Concentration and Migration Patterns in Russia. Working Paper. No 4, Montpellier: MOISA.

Coelho P., Ghali M. (1971) The End of the North-South Wage Differential // American Economic Review, no 61,pp. 932-937.

De Haas H. (2010) Migration and Development: A Theoretical Perspective // International Migration Review, vol. 44, no 1, pp. 227-264.

Dølvik J.E., Eldring L. (2006) The Nordic Labour Market Two Years after the EU Enlargement. Mobility, Effects and Challenges, Copenhagen: Ekspressen Tryk \& Kopicenter.

Emelyanova A. (2017) Population Projections of the Arctic by Levels of Education. Working Paper WP-17-022. The International Institute for Applied Systems Analysis, Laxenburg, Austria.

Emelyanova A. (2018) Exploring the Future Population and Educational Dynamics in the Arctic: 2015 to 2050 // Yearbook of Population Research in Finland, vol. 53, pp. 1-24.

Foldspang L., Lange P., Puggaard K.M., Sæther E.M., Bakken L., Madsen P.K., Hensing G., Brøgger B., Avset B.S. (2013) How Can Working Life Policies Contribute to Improving the Framework Conditions? Key Findings and Policy Recommendations of the Nordic Council of Ministers' Globalisation Project, Copenhagen: Rosendahls-Schultz Grafisk.

Fujita M., Krugman P., Venables A.J. (1999) The Spatial Economy: Cities, Regions and International Trade, Massachusetts: The MIT Press.

Glaeser E.L., Mare D.C. (2001) Cities and Skills // Journal of Labor Economics, vol. 19, no 2, pp. 316-342.

Greenwood M., Hunt G., Rickman D., Treyz G. (1991) Mirgation, Regional Equilibrium, and the Estimation of Compensating Differentials // American Economic Review, vol. 81, no 5, pp. 1382-1390. 
Hamilton L., Mitiguy A. (2009) Visualizing Population Dynamics of Alaska's Arctic Communities // Arctic, vol. 62, no 4, pp. 393-398.

Hansen K.G., Bitsch S., Zalkind L. (eds.) (2013) Urbanization and the Role of Housing in the Present Development Process in the Arctic, Nordregio.

Hansen K.G., Rasmussen R.O., Olsen L.S., Roto J., Fredricsson C. (2012) Megatrends in the Arctic: New Inspiration into Current Policy Strategies, Stockholm: Nordregio.

Heleniak T. (2014) Migration in the Arctic // Arctic Yearbook: Human Capital in the North, Akureyri, Iceland: Northern Research Forum, pp. 82-104.

Heleniak T., Bogoyavlensky D. (2015) Arctic Populations and Migration // Arctic Human Development Report: Regional Processes and Global Linkages, Copenhagen: Nordisk Ministerråd, pp. 53-104.

Howe E.L. (2009) Patterns of Migration in Arctic Alaska // Polar Geography, vol. 32, no 1-2, pp. 69-89.

Howe E.L., Huskey L., Berman M.D. (2014) Migration in Arctic Alaska: Empirical Evidence of the Stepping Stone Hypothesis // Migration Studies, vol. 2, no 1, pp. 97-123.

Huskey L., Southcott C. (2010) Migration in the Circumpolar North: Issues and Contexts, Edmonton. CCI Press in Cooperation with the University of the Arctic.

Jungsberg L., Turunen E., Heleniak T., Wang S., Ramage J., Roto J. (2019) Atlas of Population, Society and Economy in the Arctic, Stockholm: Nordregio.

Karlsdóttir A., Greve Harbo L. (2017) Nordic Arctic Strategies in Overview, Stockholm: Nordregio.

Kholodilin K.A., Oshchepkov A., Siliverstovs B. (2009) The Russian Regional Convergence Process: Where Does It Go? DIW Discussion Paper. No 861.

Khoreva O., Konchakov R., Leonard C.S., Tamitskiy A., Zaikov K. (2019) Attracting Skilled Labour to the North: Migration Loss and Policy Implications across Russia's Diverse Arctic Regions // Polar Record, vol. 54, no 5-6, pp. 324-338.

Larsen J.N., Fondahl G. (eds.) (2014) Arctic Human Development Report: Regional Processes and Global Linkages, Copenhagen: Rosendahls-Schultz Grafisk.

Lehmann H., Silvagni M.G. (2013) Is There Convergence of Russia's Regions? Exploring the Empirical Evidence: 1995-2010. Discussion Paper. No 7603.

Mkrtchyan N., Karachurina L. (2015) Population Change in the Regional Centres and Internal Periphery of the Regions in Russia. Ukraine and Belarus over the Period of 1990-2000s // Bulletin of Ge-ography. Socio-economic Series, vol. 28, pp. 91-111.

Moretti E. (2011) Local Labour Markets // Handbook of Labour Economics, vol. 4B, Amsterdam: Elsevier, pp. 1237-1314.

Roback J. (1982) Wages, Rents and the Quality of Life // Journal of Political Economy, vol. 90, no 6, pp. 1257-1278.

Rolfe J., Miles B., Lockie S., Ivanova G. (2007) Lessons from the Social and Economic Impacts of the Mining Boom in the Bowen Basin 2004-2006 // Australasian Journal of Regional Studies, vol. 13, no 2, pp. 134-153.

Rosen S. (1979) Wagebased Indexes of Urban Quality of Life // Current Issues in Urban Economics (eds. Miezkowski P., Straszheim M.), Baltimore: Johns Hopkins University Press, pp. 74-104.

Samet K. (2013) Circular Migration between the North and the South: Effects on the Source Southern Economies // Procedia - Social and Behavioral Sciences, vol. 93, pp. 225-242.

Sardadvar S., Vakulenko E. (2016) Interregional Migration within Russia and its East-West Divide: Evidence from Spatial Panel Regressions // Review of Urban and Regional Development Studies, vol. 28, no 2, pp. 123-141.

Tano S., Pettersson Ö., Stjernström O. (2016) Labour Income Effects of the Recent "Mining Boom" in Northern Sweden // Resources Policy, vol. 49, pp. 31-40.

Wilson E., Stammler F. (2016) Beyond Extractivism and Alternative Cosmologies: Arctic Communities and Extractive Industries in Uncertain Times // The Extractive Industries and Society, vol. 3, no 1, pp. 1-8. 


\title{
The Impact of Wages in the European Part of Russia on Migration in the Far North
}

\author{
M. GILTMAN*, N. OBUKHOVICH**, N. LARIONOVA***
}

\begin{abstract}
*Marina Giltman - PhD in Economics, Professor, Department of Economics and Finance, University of Tyumen. Address: 6, Volodarsky St., Tyumen, 625003, Russian Federation. E-mail: giltman@rambler.ru

** Natalia Obukhovich - PhD in Economics, Associate Professor, Department of Economics and Finance, University of Tyumen. Address: 6, Volodarsky St., Tyumen, 625003, Russian Federation. E-mail: o.n.v@mail.ru

***Natalia Larionova - PhD in Economics, Associate Professor, Department of Economic Theory and Econometrics, Kazan Federal University. Address: 18, Kremlyovskaya St., Kazan, 420008, Russian Federation. E-mail: natasha-lari@mail.ru

Citation: Giltman M., Obukhovich N., Larionova N. (2020) The Impact of Wages in the European Part of Russia on Migration in the Far North. Mir Rossii, vol. 29, no 3, pp. 28-50 (in Russian). DOI: 10.17323/1811-038X-2020-29-3-28-50
\end{abstract}

\begin{abstract}
This article analyzes the population decline in the Russian North associated with the outmigration of the labor force. First, we review previous empirical studies and show that migration to the North was previously driven by labor demand in the mining and extractive industries. However, higher economic development in the European part of Russia might also have had an impact on the migration to the Far North. In particular, we hypothesize that rising wages in the European part of Russia negatively affected such migration. We use official panel statistics on 65 Russian regions (53 in the European part and 12 in the Far North) over the period 2010-2017 and test this conjecture econometrically by estimating a fixed-effects model with a spatial lag. The model accounts for regional economic development, labor market characteristics, macroeconomic shocks, labor force education and other relevant parameters. We show that out-migration from the Far North was positively associated with increasing wages in the European part of Russia. However, we also find that increasing wages in some regions of the North partly counteracted this process. We conclude with policy implications for the development of the Arctic zone, such as increasing state support to boost the demand for labor in the Northern regions.
\end{abstract}

Key words: Arctic, wage, labor demand, migration, local labor markets, Arctic population, population of the North, compensating differentials

\section{References}

Bignebat C. (2003) Spatial Dispersion of Wages in Russia: Does Transition Reduce Inequality on Regional Labour Markets? Paris: TEAM, University of Paris1\&CNRS. 
Bignebat C. (2006) Labour Market Concentration and Migration Patterns in Russia. Working Paper. No 4, Montpellier: MOISA.

Bogoyavlenskij V.I., Bogoyavlenskij I.V. (2017) Strategiya osvoeniya resursov nefti i gaza Arktiki - obespechenie energeticheskoj, ekologicheskoj i ekonomicheskoj bezopasnosti Rossii [The Strategy for Extracting Arctic Oil and Gas - the Provision of Russia's Economic, Environmental and Energetic Security]. Geopolitika i bezopasnost', no 3, pp. 72-86.

Buranshina N.A., Smirnykh L.I. (2018) Chelovecheskij kapital migrantov i konvergentsiya rossijskikh regionov po zarabotnoj plate [Human Capital and the Convergence of Wages in Russian Regions]. Voprosy Ekonomiki, no 12, pp. 121-138.

Coelho P., Ghali M. (1971) The End of the North-South Wage Differential. American Economic Review, no 61, pp. 932-937.

De Haas H. (2010) Migration and Development: A Theoretical Perspective. International Migration Review, vol. 44, no 1, pp. 227-264.

Demidova O. (2014) Prostranstvenno-avtoregressionnaya model' dlya dvukh grupp vzaimosvyazannykh regionov (na primere vostochnoj i zapadnoj chasti Rossii [A Spatialautoregressive Model for the Two Groups of Related Regions (Eastern and Western Parts of Russia)]. Applied Econometrics, no 34(2), pp. 19-35.

Dølvik J.E., Eldring L. (2006) The Nordic Labour Market Two Years after the EU Enlargement. Mobility, Effects and Challenges, Copenhagen: Ekspressen Tryk \& Kopicenter.

Emelyanova A. (2017) Population Projections of the Arctic by Levels of Education. Working Paper WP-17-022. The International Institute for Applied Systems Analysis, Laxenburg, Austria.

Emelyanova A. (2018) Exploring the Future Population and Educational Dynamics in the Arctic: 2015 to 2050. Yearbook of Population Research in Finland, vol. 53, pp. 1-24.

Fauzer V.V., Smirnov A.V. (2018) Mirovaya Arktika: prirodnye resursy, rasselenie naseleniya, ekonomika [The World's Arctic: Natural Resources, Population Distribution]. Arctic: Ecology and Economy, no 3(31), pp. 6-22.

Foldspang L., Lange P., Puggaard K.M., Sæther E.M., Bakken L., Madsen P.K., Hensing G., Brøgger B., Avset B.S. (2013) How Can Working Life Policies Contribute to Improving the Framework Conditions? Key Findings and Policy Recommendations of the Nordic Council of Ministers ' Globalisation Project, Copenhagen: Rosendahls-Schultz Grafisk.

Fujita M., Krugman P., Venables A.J. (1999) The Spatial Economy: Cities, Regions and International Trade, Massachusetts: The MIT Press.

Giltman M.A. (2017) Zanyatost' na Severe Rossii: analiz na osnove mikrodannykh [Employment in the North of Russia: a Microdata Analysis]. Journal of the New Economic Association, no 3(35), pp. 103-124.

Giltman M.A., Obukhovich N.V., Tokareva O.E. (2019) Aktivnaya i passivnaya politika na rossijskom rynke truda: tsentralizatsiya ili regionalizatsiya? [Active and Passive Policies on the Russian Labor Market: Centralization or Regionalization?]. Voprosy Ekonomiki, no 6, pp. 79-98.

Glaeser E.L., Mare D.C. (2001) Cities and Skills. Journal of Labor Economics, vol. 19, no 2, pp. 316-342.

Greenwood M., Hunt G., Rickman D., Treyz G. (1991) Mirgation, Regional Equilibrium, and the Estimation of Compensating Differentials. American Economic Review, vol. 81, no 5, pp. 1382-1390.

Hamilton L., Mitiguy A. (2009) Visualizing Population Dynamics of Alaska's Arctic Communities. Arctic, vol. 62, no 4, pp. 393-398.

Hansen K.G., Bitsch S., Zalkind L. (eds.) (2013) Urbanization and the Role of Housing in the Present Development Process in the Arctic, Nordregio.

Hansen K.G., Rasmussen R.O., Olsen L.S., Roto J., Fredricsson C. (2012) Megatrends in the Arctic: New Inspiration into Current Policy Strategies, Stockholm: Nordregio.

Heleniak T. (2014) Migration in the Arctic. Arctic Yearbook: Human Capital in the North, Akureyri, Iceland: Northern Research Forum, pp. 82-104.

Heleniak T., Bogoyavlensky D. (2015) Arctic Populations and Migration. Arctic Human Development Report: Regional Processes and Global Linkages, Copenhagen: Nordisk Ministerråd, pp. 53-104. 
Howe E.L. (2009) Patterns of Migration in Arctic Alaska. Polar Geography, vol. 32, no 1-2, pp. 69-89.

Howe E.L., Huskey L., Berman M.D. (2014) Migration in Arctic Alaska: Empirical Evidence of the Stepping Stone Hypothesis. Migration Studies, vol. 2, no 1, pp. 97-123.

Huskey L., Southcott C. (2010) Migration in the Circumpolar North: Issues and Contexts, Edmonton. CCI Press in Cooperation with the University of the Arctic.

Jungsberg L., Turunen E., Heleniak T., Wang S., Ramage J., Roto J. (2019) Atlas of Population, Society and Economy in the Arctic, Stockholm: Nordregio.

Kapeliushnikov R., Oshchepkov A. (2014) Rossijskij rynok truda: paradoksy postkrizisnogo razvitiya [The Russian Labor Market: Paradoxes of Post-crisis Performance]. Voprosy Ekonomiki, no 7, pp. 66-92.

Karlsdóttir A., Greve Harbo L. (2017) Nordic Arctic Strategies in Overview, Stockholm: Nordregio.

Kholodilin K.A., Oshchepkov A., Siliverstovs B. (2009) The Russian Regional Convergence Process: Where Does It Go? DIW Discussion Paper. No 861.

Khoreva O., Konchakov R., Leonard C.S., Tamitskiy A., Zaikov K. (2019) Attracting Skilled Labour to the North: Migration Loss and Policy Implications across Russia's Diverse Arctic Regions. Polar Record, vol. 54, no 5-6, pp. 324-338.

Kolomak E.A. (2010) Prostranstvennye eksternalii kak resurs ekonomicheskogo rosta [Spatial Externalities as a Source of Economic Growth]. Region: Economics and Sociology, no 4, pp. 73-87.

Kryukov V.A. (2019) Monogoroda i osvoenie syr'evykh resursov na stadii vysokoj stepeni zrelosti resursnoj bazy [The Monotowns and Resource Development in the Era of Highly Developed Resource Base]. Bulletin of Kemerovo State University. Series: Political, Sociological and Economic Sciences, no 1, pp. 98-105.

Larsen J.N., Fondahl G. (eds.) (2014) Arctic Human Development Report: Regional Processes and Global Linkages, Copenhagen: Rosendahls-Schultz Grafisk.

Lehmann H., Silvagni M.G. (2013) Is There Convergence of Russia's Regions? Exploring the Empirical Evidence: 1995-2010. Discussion Paper. No 7603.

Mkrtchyan N., Karachurina L. (2015) Population Change in the Regional Centres and Internal Periphery of the Regions in Russia. Ukraine and Belarus over the Period of 1990-2000s. Bulletin of Ge-ography. Socio-economic Series, vol. 28, pp. 91-111.

Moretti E. (2011) Local Labour Markets. Handbook of Labour Economics, vol. 4B, Amsterdam: Elsevier, pp. 1237-1314.

Pilyasov A.N. (2015) Rossijskij arkticheskij frontir: paradoksy razvitiya [Russian Arctic Frontier: Paradoxes of Development]. Region: Economics and Sociology, no 3(87), pp. 3-36.

Pilyasov A.N. (2018) Arkticheskaya diagnostika: plokh ne metr - yavlenie drugoe [Arctic Diagnostics: Bad Is Not a Meter - This Is Another Phenomenon]. The North and the Market: Forming the Economic Order, no 5(61), pp. 35-54.

Roback J. (1982) Wages, Rents and the Quality of Life. Journal of Political Economy, vol. 90, no 6 , pp. 1257-1278.

Rolfe J., Miles B., Lockie S., Ivanova G. (2007) Lessons from the Social and Economic Impacts of the Mining Boom in the Bowen Basin 2004-2006. Australasian Journal of Regional Studies, vol. 13, no 2, pp. 134-153.

Rosen S. (1979) Wagebased Indexes of Urban Quality of Life. Current Issues in Urban Economics (eds. Miezkowski P., Straszheim M.), Baltimore: Johns Hopkins University Press, pp. 74-104.

Samet K. (2013) Circular Migration between the North and the South: Effects on the Source Southern Economies. Procedia - Social and Behavioral Sciences, vol. 93, pp. 225-242.

Sardadvar S., Vakulenko E. (2016) Interregional Migration within Russia and its East-West Divide: Evidence from Spatial Panel Regressions. Review of Urban and Regional Development Studies, vol. 28, no 2, pp. 123-141.

Silin A.N. (2015) Sotsiologicheskie aspekty vakhtovogo truda na territoriyakh severa Zapadnoj Sibiri [Sociological Aspects of Rotational Employment in the Northern Territories of Western Siberia]. Economic and Social Changes: Facts, Trends, Forecast, no 4(40), pp. 109-123. 
Sokolova F.Kh. (2016) Migratsionnye protsessy v Rossijskoj Arktike [Migration Processes in the Russian Arctic]. Arctic and North, no 25, pp. 158-172.

Syurin S.A., Kovshov A.A. (2019) Usloviya truda i risk professional'noj patologii na predpriyatiyakh Arkticheskoj zony Rossijskoj Federatsii [Labor Conditions and the Risk of Professional Deficiency at the Enterprises of the Arctic Zone of the Russian Federation]. Human Ecology, no 10, pp. 15-23.

Tano S., Pettersson Ö., Stjernström O. (2016) Labour Income Effects of the Recent "Mining Boom" in Northern Sweden. Resources Policy, vol. 49, pp. 31-40.

Trofimov S.E. (2019) Arkticheskij shel'f kak strategicheskij region razvitiya rossijskoj ekonomiki [Arctic Shelf as a Strategic Region of Development of the Russian Economy]. Voprosy Ekonomiki, no 7, pp. 147-160.

Vorontsova E.V., Vorontsov A.L. (2019) Sostoyanie okruzhayushchej sredy i zdorov'e cheloveka v Arkticheskoj meditsine: meditsinskij i sotsial'no-pravovoj aspekt [Environmental State and Human Health in the Arctic Zone: Medical and Socio-legal Aspects]. Yakut Medical Journal, no 3, pp. 85-90.

Wilson E., Stammler F. (2016) Beyond Extractivism and Alternative Cosmologies: Arctic Communities and Extractive Industries in Uncertain Times. The Extractive Industries and Society, vol. 3, no 1, pp. 1-8.

Zamyatina N.Yu., Pilyasov A.N. (2017) Kontseptsiya blizosti: zarubezhnyj opyt i perspektivy primeneniya v Rossii [The Concept of Proximity: Foreign Experience and the Prospects of Application in Russia]. Izvestiya Rossiiskoj Akademii Nauk. Seriya Geograficheskaya, no 3 , pp. 8-21. 